\title{
PARTISIPASI MASYARAKAT DALAM PROGRAM PENGELOLAAN SAMPAH
}

\author{
Oleh: \\ Mamah Halimah, Hetty Krisnani, \& Muhammad Fedryansyah
}

Email:

mamahhalimah01@gmail.com; hettykrisnani@yahoo.com; fedry_cons@yahoo.com

\begin{abstract}
ABSRAK
Sampah merupakan material sisa yang dihasilkan dari aktivitas manusia, hewan, dan alam yang sudah tidak digunakan lagi dan tidak memiliki nilai ekonomis. Sampah apabila dibiarkan saja tanpa ada pengelolaan akan menimbulkan berbagai macam masalah baik itu masalah lingkungan fisik, kesehatan manusia, keindahan estetika, dan masalah sosial. Untuk mengatasi volume sampah yang semakin meningkat, maka pengelolaan sampah sangat dibutuhkan. Pengelolaan sampah dilakukan yaitu untuk mengurangi volume timbulan sampah bahkan dapat memusnahkan sampah dari muka bumi ini dengan syarat seluruh manusia sadar akan bahayanya sampah. Dalam melakukan pengelolaan sampah tidak cukup dilakukan oleh pemerintahan saja melainkan masyarakat juga harus ikut terlibat dalam mengatasi masalah sampah ini karena sampah jika dikelola oleh masyarakat akan berdampak positif bagi kehidupan mereka. Oleh karena itu, partisipasi masyarakat sangat penting bagi peningkatan kualitas manusia agar dapat meningkatkan partisipasi secara nyata dalam berbagai aktifitas kehidupan untuk mendorong terciptanya kegiatan produktif yang bernilai tinggi. Dengan demikian, dalam pengolahan sampah dibutuhkan teknik pengembangan masyarakat yang bertujuan untuk meningkatkan kemampuan masyarakat dalam mengatasi lingkungannya.

Kata kunci: Pengelolaan sampah, partisipasi masyarakat dan Pengembangan Masyarakat.
\end{abstract}

\section{Pendahuluan}

Indonesia merupakan sebuah negara yang jumlah penduduknya menduduki peringkat ke empat di dunia. Jumlah penduduk Indonesia berdasarkan sensus penduduk 2010 sebanyak 237.641.326 jiwa yang berbanding lurus dengan produksi sampah setiap harinya. Pada tahun 2025 mendatang, produksi sampah diperkirakan akan mencapai 130.000 ton perhari. Pasalnya aktivitas masyarakat pada umumnya akan berhubungan dengan konsumsi makanan dalam kemasan setiap harinya. Oleh karena itu, volume sampah dari tahun ketahun akan semakin meningkat karena hitungan rata-rata setiap orang diperkirakan membuang sampah $0,5 \mathrm{~kg}$ sampah perhari. Maka sampah yang paling dominan adalah sampah rumah tangga yaitu sebanyak 48 persen. (sumber: medialingkungan.com)

Berdasarkan hasil studi pada tahun 2008 yang dilakukan di beberapa kota, pola pengelolaan sampah di Indonesia menurut rasio adalah diangkut dan ditimbun di TPA sebesar 69 persen, dikubur sebesar 10 persen, dikompos dan didaur ulang sebesar 7 persen, dibakar sebesar 5 persen, dan sisanya tidak terkelola. (sumber: liputan6.com)

Meningkatnya volume timbulan sampah tentunya memerlukan upaya pengelolaan agar masyarakat terhindar dari permasalahan lingkungan yang disebabkan oleh sampah. Selain itu, pengelolaan sampah yang dilakukan juga perlu menggunakan metode dan teknik-teknik yang baik. 
Pengelolaan sampah yang tidak mempergunakan metode dan teknik pengelolaan sampah yang ramah lingkungan, selain dapat menimbulkan dampak negatif terhadap kesehatan juga akan sangat menganggu kelestarian fungsi lingkungan baik lingkungan pemukiman, hutan, persawahan, sungai dan lautan.

Dalam PP nomor 81 tahun 2012 pasal 1 ayat 3 mengatakan bahwa pengelolaan sampah adalah kegiatan yang sistematis, menyeluruh, dan berkesinambungan yang meliputi pengurangan dan penanganan sampah. Pasal 2 menjelaskan bahwa pengaturan pengelolaan sampah bertujuan; a. Menjaga kelestarian fungsi lingkungan hidup dan kesehatan masyarakat; dan b. Menjadikan sampah sebagai sumber daya.

Pelaksanaan program pengelolaan sampah oleh pemerintah berupa ditimbun dan dibakar. sedangkan apabila pengelolaan sampah dilakukan oleh masyarakat, sampah akan terkelola dan teratasi dengan baik dan akan berdampak positif. Ada beberapa kota yang dijadikan percontohan mengenai pengelolaan sampah yang sudah berhasil, salah satunya kota Surabaya, Malang, dan Jombang.

Surabaya menjadi salah satu kota di Indonesia yang dinilai mampu mengelola sampah dengan baik, melalui 3R (reduce, seuse, recycle). Tidak hanya itu, program 3R dinilai telah menjadi landasan upaya pengelolaan sampah secara mandiri oleh masyarakat, dalam ranga mengurangi sampah dan mengambil nilai ekonomis dari sampah. Hal ini, menjadikan kota Surabaya sebagai role model negara-negara di Asia Pasifik. Kunci sukses keberhasilan program pengelolaan sampah sampah terletak pada peran serta aktif masyarakat beserta seluruh elemen yang ada. Keterlibatan semua pihak dalam upaya mengurangi sampah, menjadikan program 3R dapat berjalan dengan baik.

Dengan demikian, pengelolaan sampah yang dilakukan oleh pemerintah tidak semuanya dapat mengatasi masalah volume sampah karena dengan hal tersebut akan menimbulkan masalah baru lainnya. Maka pengelolaan sampah sebaiknya dikelola oleh semua pihak yaitu pihak dari pemerintah, pihak swasta, dan masyarakat.

Pelaksanaan pengelolaan sampah dilakukan dengan menggunakan metode/teknik community development. Pengembangan masyarakat menurut herbert J. Rubin and Irene S. Rubin. Mendefinisikan sebagai:

"suatu upaya pengembangan masyarakat lokal (local Empowering) melalui kegiatan kolektif dari kelompok-kelompok yang terorganisir untuk mengontrol keputusan, proyek, program, dan kebijakan yang mempengaruhi mereka sebagai sebuah komunitas. Dalam model ini digunakan berbagai pendekatan dan teknik pada masyarakat lokal yang terorganisasikan sebagai upaya untuk mendorong prakarsa dan kepemimpinan lokal sebagai sarana perubahan primer" (diterjemahkan)

Dari uraian diatas dapat disimpulkan bahwa pengembangan masyarakat adalah suatu proses yang dirancang untuk membuat kondisi ekonomi dan sosialnya maju dengan melibatkan partisipasi masyarakat secara penuh sehingga dapat menciptakan prakarsa masyarakat itu sendiri. Sedangkan tujuan dari pengembangan masyarakat yaitu untuk meningkatkan kemampuan masyarakat dalam mengatasi masalah lingkungannya. Maka metode tersebut melibatkan partisipasi dari masyarakat agar Indonesia bebas dari sampah.

\section{Pengelolaan Sampah}

Sampah adalah suatu bahan yang terbuang atau dibuang dari sumber hasil aktivitas manusia maupun alam yang belum memiliki nilai ekonomis. Sampah bisa dari berbagai macam bentuk, yaitu bentuk sampah padat, cair, dan gas. Akan tetapi, secara sederhana jenis sampah bisa terbagi menjadi dua bagian, sampah organik dan sampah anorganik. Sampah organik merupakan sampah yang dihasilkan dari makhluk hidup. Sedangkan sampah anorganik merupakan sampah tidak dapat terurai seperti karet, plastik, kaleng, dll. Sampah apabila dibiarkan saja tanpa ada pengelolaan akan menimbulkan berbagai macam masalah baik itu masalah lingkungan fisik, kesehatan manusia, dan 
masalah sosial. Sementara apabila sampah dikelola akan menciptakan sebuah peluang untuk dijakikan bisnis, lapangan pekerjaan, sumber energi, dan didaur ulang sehingga sampah dapat bermanfaat dan dapat menghasilkan nilai ekonomis. Maka dari itu pengelolaan sampah sangat dibutuhkan.

Pengelolaan sampah adalah pengumpulan, pengangkutan, pemprosesan, pendaur ulangan dari material sampah. Pengelolaan sampah biasanya mengacu pada material sampah yang dihasilkan dari kegiatan manusia dan biasanya dikelola untuk mengurangi dampaknya terhadap kesehaan dan lingkungan. Pengelolaan sampah juga dilakukan untuk memperbaiki sumber daya alam yang sudah rusak. Dalam pengelolaan sampah agar dapat tercipta dan terlaksana dengan baik maka diperlukan peran serta atau partisipasi dari masyarakat.

\section{Partisipasi Masyarakat}

partisipasi masyarakat sering kali dianggap sebagai bagian yang tidak terlepas dalam upaya pengembangan masyarakat. Dengan melihat partisipasi masyarakat sebagai kesatuan dalam proses pengembangan masyarakat, akan dapat diketahui bahwa akar perkembangan pemikiran tentang partisipasi masyarakat dalam pengelolaan sampah akan terkait dengan siskursus komuitas. Partisipasi masyarakat adalah keikutsertaan masyarakat dalam proses pengidentifikasian masalah dan poetensi yang ada dimasyarakat, pemilihan dan pengambilan keputusan tentang alternatif solusi untuk menangani masalah, pelaksanaan upaya mengatasi masalah, keterlibatan masyarakat dalam proses mengevaluasi perubahan yang terjadi.

Berangkat dari paparan diatas, menunjukkan bahwa partisipasi dari masyarakat dalam pelaksanaan sebuah program pengelolaan sampah sangaat diperlukan, karena masyarakatlah yang pada akhirnya akan melaksanakan program tersebut. Adanya pelibatan masyarakat memungkinkan mereka memiliki rasa tanggung jawab terhadap keberlanjutan sebuah program. Dengan pendekatan partisipatif, diharapkan partisipatf, potensi dan kreativitas masyarakat akan dapat lebih tergali.

Mikkelsen membuat daftar atau klasifikasi dari para praktisi pengelolaan sampah mengenai arti dari partisipasi. Pertama, Partisipasi diartikansebagai pemekaan (membuat peka) pihak masyarakat untuk meningkatkan kemauan menerima dan kemampuan untuk menanggapi proyekproyek pengelolaan sampah. Pemaknaan seperti ini agaknya kurang tepat karena memaknai partisipasi hanya sekedar meminta dukungan masyarakat terhadap semua program yang telah disiapkan. Pertemuan (rapat) dengan dalih partisipasi (minta masukan dari warga masyarakat) yang dilaksanakan tidak lebih sebagai ajang formalitas untuk menjalankan sebuah kebijakan yang telah dibuat. Hal demikian akan memunculkan partisipasi yang semu karena masyarakat tidak diberi hak untuk merancang program kecuali hanya sekedar diajak, dibujuk, diperintah dan bahkan dipisahkan oleh kelembagaan tertentu untuk ikut serta dalam suatu program yang telah dirancang sebelumnya.

Kedua, Partisipasi diartikan sebagai kontribusi sukarela dari masyarakat kepada proyek tanpa ikut serta dalam pengambilan keputusan. Pemaknaan ini hampir sama dengan pemaknaan yang pertama, yang membedakan adalah kontribusi sukarela masyarakat kepada proyek. Karena itu akhir capaian dari partisipasi jenis ini adalah penghematan biaya. Masyarakat harus mendukung atau ikut program-program pemerintah secara gratis dengan alasan program-program tersebut pada akhirnya digunakan untuk kepentingan masyarakat. Proyek-proyek pengelolaan sampah yang memiliki anggaran tertentu harus dapat diselesaikan melalui penghematan-penghematan. Makin banyak penghematan atau makin murah biaya suatu proyek, maka dapat diartikan makin besar pula partisipasi masyarakat. Disini partsipasi diartikan sebagai besarnya dana yang dapat dihemat atau dana yang dapat disediakan sebagai sumbangan atau kontribusi masyarakat kepada proyek-proyek pemerintah.

Ketiga, Partisipasi adalah suatu proses keterlibatan secara aktif dalam pengambilan kepurusan bersama dengan pemerintah. Pemaknaan seperti partisipasi masyarakat dalam program pengolahan sampah ini memberikan keterlibatan yang luas dalam tiap proses pengelolaan sampah yaitu mulai dari: 1). Keterlibatan pada identifikasi masalah, dimana masyarakat bersama-sama dengan para 
perencana atau pemegang otoritas kebijakan mengidentifikasi persoalan, mengidentifikasi peluang, potensi dan hambatan. 2). Proses perencanaan, dimana masyarakat dilibatkan secara aktif dalam penyusunan rencana dan strategi berdasar pada hasil identifikasi sebelumnya. 3). Pelaksanaan pengolahan sampah. 4). Evaluasi, yaitu masyarakat dilibatkan untuk menilai hasil pengelolaan sampah yang telah dilakukan, apakah pengelolaan sampah memberikan manfaat bagi masyarakat atau justru sebaliknya masyarakat dirugikan dengan proses yang telah dilakukan. 5). Monitoring dan 6). Mitigasi, yaitu terlibat dalam mengukur dan mengurangi dampak negatif yang diakibatkan oleh proyek yang sedang dilaksanakan.

Keempat, Partisipasi diartikan sebagai keterlibatan sukarela oleh masyarakat dalam perubahan yang ditentukannya sendiri. Inti dari partisipasi ini adalah sikap sukarela masyarakat untuk membantu keberhasilan program pengelolaan sampah yang telah ditentukan sendiri. Keterlibatan sukarela itu bisa berupa terlibat dalam proses penentuan arah, strategi dan kebijakan pengelolaan sampah, terlibat dalam memikul beban dan tanggungjawab dalam pelaksanaan pengelolaan sampah dan terlibat dalam memilih hasil dan manfaat pengelolaan sampah secara berkeadilan.

Kelima, Partsipasi adalah keterlibatan masyarakat dalam pengelolaan sampah diri, kehidupan dan lingkungan mereka. Partisipasi dalam pengertian ini sesuai dengan konsep pengembangan masyarakat, dimana dalam pengembangan masyarakat, masyarakat secara bersama-sama mengidentifikasi kebutuhan dan masalahnya, bersama-sama mengupayakan jalan keluarnya dengan jalan memobilisasikan segala sumber daya yang diperlukan serta secara bersama-sama merencanakan dan melaksanakan kegiatan untuk mencapai tujuan yang diinginkan.

Masyarakat merupakan salah salah bagian penting yang akan berpengaruh terhadap tegaknya negara dan tercapainya tujuan nasional. Oleh karena itu, dalam diri masyarakat harus tumbuh suatu kesadaran akan keberadaannya sehingga timbul hasrat untuk turut serta bersama pemerintah dalam membangun negara. Salah satu upaya yang dapat dilakukan oleh seorang warga masyarakat adalah dengan berpartisipasi secara aktif dalam berbagai kegiatan pengelolaan sampah di wilayahnya. Partisipasi selalu dikaitkan dengan peran serta.

Partisipasi tidak hanya berupa keterlibatan secara fisik dalam pekerjaan, tetapi menyangkut keterlibatan diri seseorang sehingga timbul tanggungjawab dan sumbangan yang besar terbadap kelompok. Dengan kata lain, partisipasi berarti kesediaan untuk membantu berhasilnya setiap program sesuai dengan kemampuan setiap orang tanpa mengorbankan kepentingan diri sendiri. Partisipasi berfungsi sebagal suatu kemitraan (partnership) dalam pengelolaan sampah. Partisipasi masyarakat dapat tercipta apabila saling percaya dan saling pengertian antara perangkat pemerintah dan lembaga-lembaga atau anggota masyarakat dapat dihidupkan. Kondisi yang saling percaya dan saling pengertian tidak tumbuh begitu saja, tetapi harus terdapat pandangan saling menolong, saling percaya, dan jujur antara aparat dengan masyarakat. Masyarakat adalah kelompok manusia yang dapat bekerja sama sehingga mereka dapat mengorganisasikan dirinya dan berpikir tentang dirinya sebagai suatu kesatuan sosial dengan batas tertentu. Penjelasan tersebut sama dengan konsep pengembangan masyarakat.

\section{Pengembangan Masyarakat (Community Development)}

Konsep atau metode pengembangan masyarakat (community development) berasal dari pengorganisasian masyarakat (community organization); yang bermakna mengorganisasikan masyarakat sebagai sebuah sistem untuk melayanai warganya dalam setting kondisi yang terus berubah. Dengan demikian inti pengertiannya adalah mendorong warga masyarakat untuk mengorganisasikan diri untuk melaksanakan kegiatan guna mencapai kesejahteraan sendiri.

Pengembangan masyarakat sebagai sebuah model pengembangan masyarakat yang menekankan pada partisipasi penuh seluruh warga masyarakat. Sedangkan PBB (1955) mendefinisikan pengembangan masyarakat sebagai suatu proses yang dirancang untuk menciptakan kemajuan kondisi ekonomi dan sosial bagi seluruh warga masyarakat dengan partisipasi aktif dan 
sejauh mungkin menumbuhkan prakarsa masyarakat itu sendiri. Pengembangan masyarakat sebagai sebuah proses tindakan sosial yang mendorong warga suatu masyarakat untuk:

a. Mengorganisasikan diri mereka sendiri utnuk menyusun rencana dan melaksanakan tindakan bersama.

b. Merumuskan kebutuhan-kebutuhan dan masalah-masalah bersama

c. Menyusun rencana kelompok dan individu untuk memenuhi kebutuhan dan memecahkan masalah mereka sendiri.

d. Melaksanakan rencana tersebut dengan sebanyak mungkin mengandalkan sumber-sumber yang ada.

e. Menjangkau akses terhadap sumber-sumber diluar masyarakat baik dari badan-badan pemerintah maupun swasta guna mendukung sumber-sumber yang ada.

Teknik pengembangan masyarakat dalam pengelolaan sampah sangat dibutuhkan karena masyarakat dalam mengolah sampah membutuhkan pengetahuan mengenai cara-cara pengolahan sampah yang benar. Oleh karena itu, dalam mengolah sampah dibutuhkan pengembangan yang diberikan oleh pemerintah dan atau oleh masyarakat yang sudah ahli dalam mengolah sampah. Sehingga masyarakat bisa mengolah sampahnya sendiri. Sejalan dengan pengembangan masyarakat menurut Rudito Bambang adalah suatu proses sosial dimana manusia dapat menjadi lebih kompeten untuk hidup dengan dan mempunyai sebuah kontrol atas sumber daya lokal. Tujuan akhir dari pengembangan masyarakat adalah peningkatan kemampuan masyarakat dalam mengatasi masalah linkungannya sendiri.

Pengembangan masyarakat dibutuhkan juga partisipasi dari masyarakat. Adanya pengembangan masyarakat dalam pengolahan sampah akan menumbuhkan partisipasi baik dengan sendirinya maupun disebabkan oleh faktor lain. Partisipasi dapat tumbuh dengan sendirinya apabila segala kegiatan yang akan dilaksanakan memberikan manfaat bagi kelangsungan hidup. Faktor lainnya, partisipasi dapat tumbuh karena adanya kebutuhan yang sama, kepentingan yang sama, kebiasaan yang dilakukan, maupun karena pergaulan hidup dalam bermasyarakat.

\section{Kesimpulan}

Dalam suatu program pemerintahan akan berhasil apabila masyarakat juga ikut berpartisipasi. Partisipasi masyarakat sangat dibutuhkan dan sangat penting dalam tercapainya keberhasilan program. Karena apabila melibatkan warga masyarakat, maka masyarakat akan sadar bahwa program yang dibuat merupakan program yang penting untuk pemenuhan kebutuhan masyarakat itu sendiri. Partisipasi masyarakat merupakan kesediaan untuk membantu berhasilnya setiap program sesuai dengan kemampuan setiap orang tanpa mengorbankan kepentingan diri sendiri. Partisipasi berfungsi sebagal suatu kemitraan dalam pengelolaan sampah. Partisipasi masyarakat dapat tercipta apabila saling percaya dan saling pengertian antara perangkat pemerintah dan lembaga-lembaga atau anggota masyarakat dapat dihidupkan.

\section{Referensi:}

Aziz Muslim., Pendekatan Partisipatif Dalam Pengembangan Masyarakat. Vol. VIII, No. 2Desember2007:89-103

Britha, Mikkelsen., Metode Penelitian Partisipatoris dan Upaya-upaya Pengembangan: Sebuah Buku Pegangan Bagi Para Praktisi Lapangan, Terjemahan Matheos Nalle, Jakarta: Yayasan Obor Indonesia, 2003.

Isbandi Rukminto Adi. Revisi 2012. Pengembangan Masyarakat dan Partisipasi Masyarakat. Jakarta: Raja Grafindo Persada. Hal 227,228,229,230,231

Wibhawa, Budhi., dkk. (2010). Dasar-Dasar Pekerjaan Sosial, Bandung: Widya Padjadjaran 
Rudito, Bambang dkk. 2003. Akses Peran Masyarakat "Lebih Jauh Memahami Community Develompment". Jakarta : ICSD 